\title{
Great span continuous rigid frame bridge piers earthquake response analysis
}

\author{
Xing-shun Liu ${ }^{1, a^{*}}$, Jian-tao Peng ${ }^{1, b}$, Xiao-jun Ning ${ }^{1, c}$ \\ ${ }^{1}$ Faculty of Civil Engineering and Mechanics, Kunming University of Science and \\ Technology,Kunming,China \\ aymhsslblxs@qq.com, ㄷ16672033@qq.com, ${ }^{\star}$ Corresponding author
}

\section{Keywords: Seismic response;Spectrum analysis;Continuous rigid bridge}

Abstract: In order to analyze the form of piers span continuous rigid frame bridge seismic impact on the order of a continuous rigid frame bridge engineering background, the use of large-scale professional finite element analysis software MIDAS CIVIL build dynamic analysis models were different cross-sectional forms modal pier analysis, using dynamic response spectrum analysis method to calculate the dynamic response of the structure, and comparative analysis of different results, the conclusions of large span continuous seismic analysis and design of the bridge just enough to provide relevant basis.

\section{Introduction}

Earthquake as a serious natural disaster, threat to humans as the human' material accumulating and growing. This article is based on "Seismic Design of Highway Bridges Rules" (JTJ / TB02-01-2008), using finite element software MIDAS CIVIL established a high pier continuous rigid frame bridge finite element model, using the dynamic response spectrum analysis of the bridge analysis of the seismic performance.

\section{Project overview}

The bridge is located Kunming Jiaozishan travel lanes highway span of 396m, the main axle $103+$ $190+103$ m Single Cell Box uniform continuous prestressed concrete rigid frame bridge with double thin substructure wall pier, bored pile foundation. The upper bridge main beam section is a single box single-chamber box section, box girder roof width $12 \mathrm{~m}$, bottom width $6.5 \mathrm{~m}$; the lower part of the main pier 2 are the same as the height of the cross-section of double thin - wall pier, pier height $104 \mathrm{~m}$, Two Legs and Thin sectional limb center distance $10.5 \mathrm{~m}$, vertical bridge to a single limb width $3.5 \mathrm{~m}$, the wall thickness of $0.6 \mathrm{~m}$, transverse width to a single limb $8.5 \mathrm{~m}$, the wall thickness of $1.0 \mathrm{~m}$, using C50 concrete pier body.

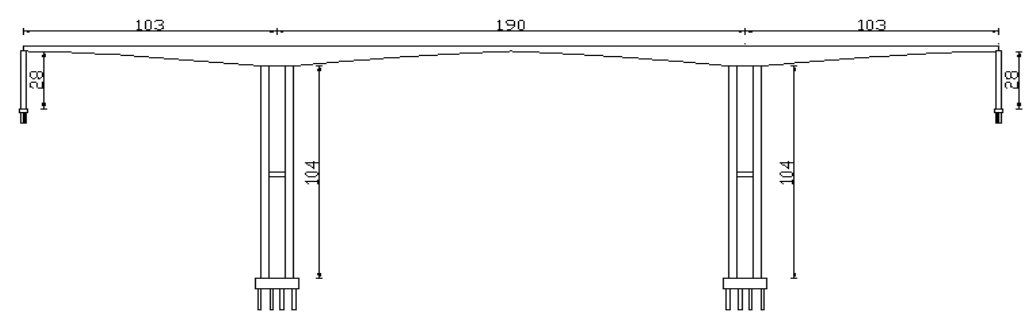

Fig. 1 Continuous rigid frame bridge finite element model 


\section{Calculated parameters}

\section{Permanent loads}

(1)The 1st phase load :Take 26 concrete density.

(2)The 2nd phase load: include pavement, crash barriers, etc. are uniformly distributed load included, the total uniform load of $71.7 \mathrm{KN} / \mathrm{m}$.

\section{accidental load}

According to "Seismic Design of Buildings" (GB50011-2001) and "China Earthquake Zoning Map" (GB18306-20).

The bridge site area seismic reflection spectrum characteristic period is $0.4 \mathrm{~S}$, the basic design earthquake acceleration is $0.2 \mathrm{~g}$, corresponding to the basic seismic intensity of seven degrees.

According to "Seismic Design of Highway Bridges Rules" (JTG / TB021-01-2008) 9.3.6 provides concrete bridges, arch bridges damping ratio should be less than 0.05 , so here take damping ratio was 0.05 . According to seismic code 9.3.1, this seismic calculation using modal response spectrum method of calculation. Level design acceleration response spectrum is determined by the following formula:

$$
\begin{aligned}
& S=\left\{\begin{array}{lc}
S_{\max }(5.5 T+0.45) & T<01 s \\
S_{\max } & 01 \mathrm{ll} \leq T \leq T_{g} \\
S_{\max }\left(T_{g} / T\right) & T>T_{g}
\end{array}\right. \\
& S_{\max }=2.25 C_{i} C_{g} C_{d} A
\end{aligned}
$$

In the formulas A is a characteristic period, $\mathrm{T}$ vibration period of the structure, $S_{\max }$ is the maximum level design acceleration response spectrum, ${ }^{C_{i}}$ is an important earthquake factor of $1.0,{ }^{C}{ }_{g}$ is the site coefficient of $1.0,{ }^{C}$ is damping adjustment factor of $1.0, \mathrm{~A}$ is horizontal to the basic design earthquake acceleration peak.

\section{Model}

Establishing full bridge finite element model of the structure by using MIDAS CIVIL 2012 of an acceleration response spectrum analysis. With considerarion of the structure of the resistance along the bridge and Transverse Direction seismic action, use the CQC modal combination method. Meanwhile according to "highway bridges and culverts foundation and foundation design specification" (JTG D63-2007) provides that the use of the interaction between the soil and the soil pile spring simulation, as realistic as possible to simulate the pile foundation.

\section{Analysis}

\section{Compare Solid with hollow pier pier}

The piers of the model were uses two kinds-section in Figure 3, another for solid piers, one for the Hollow Pier. With the analysing of the model response under seismic response spectrum, the results shown in Table 1. 

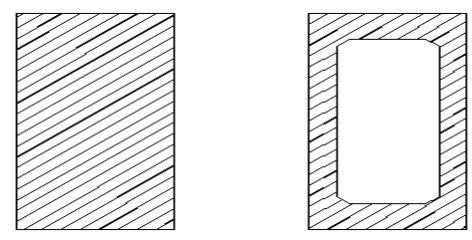

Fig. 2 Pier-section of

Table 1 Seismic Response solid and hollow pier pier

\begin{tabular}{|c|c|c|c|c|c|c|c|c|c|}
\hline \multirow{2}{*}{$\begin{array}{l}\text { Pier } \\
\text { form }\end{array}$} & \multirow{2}{*}{$\begin{array}{c}\text { Bridge } \\
\text { baseba } \\
\text { nd }\end{array}$} & \multicolumn{2}{|c|}{$\begin{array}{c}\text { Spectral response } \\
\text { acceleration }\end{array}$} & \multicolumn{2}{|c|}{$\begin{array}{c}\text { Pier top } \\
\text { displacement } \\
(\mathrm{mm})\end{array}$} & \multicolumn{2}{|c|}{$\begin{array}{c}\text { Pier bottom } \\
\text { moment }(\mathrm{KN} / \mathrm{M})\end{array}$} & \multicolumn{2}{|c|}{$\begin{array}{c}\text { Pier bottom axis } \\
\text { force }\end{array}$} \\
\hline & & $\begin{array}{l}\text { Along } \\
\text { the } \\
\text { bridge }\end{array}$ & $\begin{array}{c}\text { Transver } \\
\text { se } \\
\text { Directio } \\
\mathrm{n}\end{array}$ & $\begin{array}{l}\text { Along } \\
\text { the } \\
\text { bridge }\end{array}$ & $\begin{array}{c}\text { Trans ver } \\
\text { se } \\
\text { Directio } \\
n\end{array}$ & $\begin{array}{l}\text { Along } \\
\text { the } \\
\text { bridge }\end{array}$ & $\left|\begin{array}{c}\text { Trans ver } \\
\text { se } \\
\text { Directio } \\
n\end{array}\right|$ & $\begin{array}{l}\text { Along } \\
\text { the } \\
\text { bridge }\end{array}$ & $\begin{array}{c}\text { Trans vers } \\
\mathrm{e} \\
\text { Direction }\end{array}$ \\
\hline $\begin{array}{l}\text { Solid } \\
\text { Pier }\end{array}$ & 0.216 & 0.275 & 0.232 & 149 & 89.9 & 94127 & 120056 & 13934 & 2350 \\
\hline $\begin{array}{c}\text { Hollow } \\
\text { Pier }\end{array}$ & 0.218 & 0.263 & 0.208 & 139.9 & 82.7 & 70744 & 84562 & 10586 & 1524 \\
\hline
\end{tabular}

Table 1 can be seen when the same external dimensions piers were solid and hollow pier pier, the hollow pier fundamental frequency, spectral response acceleration, displacement and internal forces pier at the end of the pier top are less than solid pier, we can see, under the effect of the earthquake, hollow pier has an better than a solid pier seismic effect.

\section{pie rs comparison of different cross-sectional dimensions}

The piers of the model uses $8.0 * 3.5,8.0 * 4.0,8.0 * 5.0,8.0 * 4.5$ and four cross-sectional dimension, resulting in seismic response as shown in Figure 4 below: 

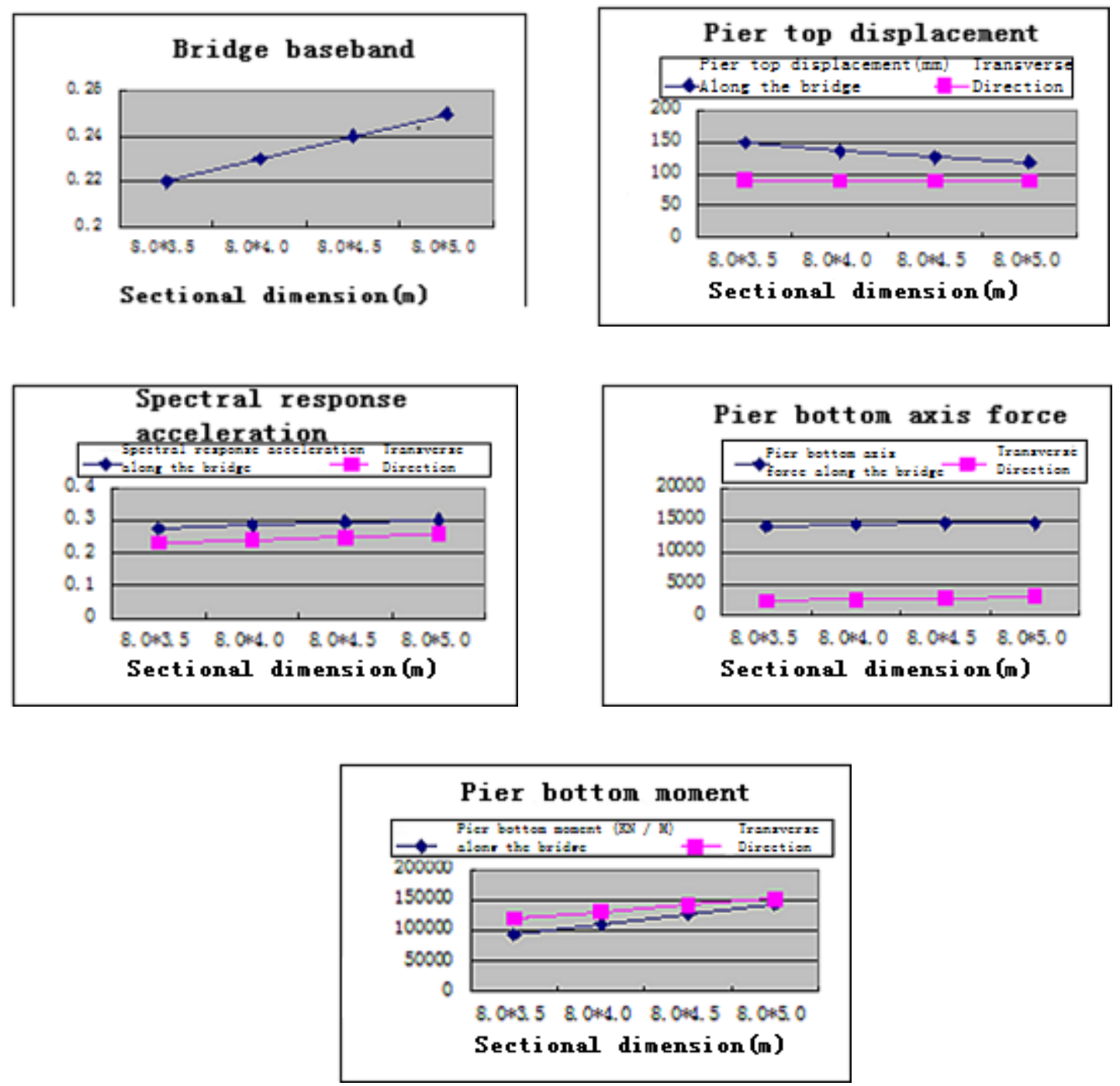

Fig. 3 Bridge pier seismic sectional dimensions vary with circumstances

As can be seen from Figure 3, the increased cross-sectional dimensions of the pier, although the pier top displacement value will be reduced, but the displacement is not obvious; while the larger cross-sectional dimension piers, the bridge, the greater the stiffness, the more the fundamental frequency large, dynamic response spectrum greater the acceleration, and increased cross-sectional dimensions of the pier will make the seismic response of the internal forces at the end of the pier becomes large. So from the point of view of seismic design, increased cross-sectional dimensions piers, would adversely earthquake.

\section{Pie r-section comparison}

Were used to model a single rectangular pier $8.0 * 7.0,6.16 \mathrm{~m}$ diameter circular and rectangular pillar pier Pier of Double Thin $8.0 * 3.5$, three-section of the area are equal, the results in the table below under seismic response as follows: 
Table 2 seismic response under different sections of the pier forms

\begin{tabular}{|c|c|c|c|c|c|c|c|c|c|}
\hline \multirow{2}{*}{$\begin{array}{l}\text { Pier } \\
\text { form }\end{array}$} & \multirow{2}{*}{$\begin{array}{c}\text { Bridge } \\
\text { baseban } \\
\text { d }\end{array}$} & \multicolumn{2}{|c|}{$\begin{array}{c}\text { Spectral response } \\
\text { acceleration }\end{array}$} & \multicolumn{2}{|c|}{$\begin{array}{c}\text { Pier top } \\
\text { displacement }(\mathrm{m} \\
\mathrm{m})\end{array}$} & \multicolumn{2}{|c|}{$\begin{array}{c}\text { Pier bottom } \\
\text { moment }(\mathrm{KN} / \mathrm{M})\end{array}$} & \multicolumn{2}{|c|}{$\begin{array}{l}\text { Pier bottom axis } \\
\text { force }\end{array}$} \\
\hline & & $\begin{array}{l}\text { Along } \\
\text { the } \\
\text { bridge }\end{array}$ & $\begin{array}{c}\text { Trans ver } \\
\text { se } \\
\text { Directio } \\
\mathrm{n}\end{array}$ & $\begin{array}{l}\text { Along } \\
\text { the } \\
\text { bridge }\end{array}$ & $\begin{array}{c}\text { Trans ver } \\
\text { se } \\
\text { Directio } \\
\mathrm{n} \\
\end{array}$ & $\begin{array}{l}\text { Along } \\
\text { the } \\
\text { bridge }\end{array}$ & $\begin{array}{c}\text { Trans ver } \\
\text { se } \\
\text { Directio } \\
\mathrm{n}\end{array}$ & $\begin{array}{l}\text { Along } \\
\text { the } \\
\text { bridge }\end{array}$ & $\begin{array}{c}\text { Trans vers } \\
\mathrm{e} \\
\text { Direction }\end{array}$ \\
\hline $\begin{array}{l}\text { Thin-w } \\
\text { alled } \\
\text { pier }\end{array}$ & 0.216 & 0.275 & 0.232 & 149.0 & 89.9 & 94127 & 120056 & 13934 & 2350 \\
\hline $\begin{array}{l}\text { Rectan } \\
\text { gular } \\
\text { Pier }\end{array}$ & 0.260 & 0.292 & 0.240 & 109.0 & 83.7 & 233447 & 30169 & 2036 & 2468 \\
\hline $\begin{array}{c}\text { Round } \\
\text { pier }\end{array}$ & 0.265 & 0.295 & 0.240 & 103.3 & 86.7 & 234668 & 29065 & 2177 & 2346 \\
\hline
\end{tabular}

Table 2 shows the result of a single rectangular piers in the three-section compared to double thin wall pier, the fundamental frequency is large, the reaction in the seismic response of a larger spectrum of acceleration, the internal forces at the end of the pier is greater, so double thin - wall pier than single rectangular pier has better seismic performance, and compared to a circular pier, the pier in seismic response of rectangular spectral response acceleration at small point, the end of the pier top displacement and internal forces of the pier or less.

\section{Summary}

Horse across the river through the earthquake response analysis of rigid frame bridge can draw the following conclusions:

1, In static structural bearing capacity to meet the design, the hollow pier with respect to the solid pier has better seismic performance.

2, In the bridge seismic design, focusing on the concept of seismic ductility, ductility plays an important role in the bridge, and control the stiffness of the piers of the bridge seis mic response, but also should consider the requirements of structural shifts in the seis mic response of the bridge.

\section{Acknowledgements}

This work was financially supported by the National Science Foundation of China (51068012) and the Yunnan Province Communications DepartmentScience and Technology Program (2013(c)07).

\section{Reference:}

[1] The People's Republic of China Ministry of Construction .GB50011-2001 "Seismic Design of Buildings" [S] Beijing: China Building Industry Press .2002

[2] Highway Planning and Design Institute Limited .JTG D63-2007 "highway bridges and culverts foundation and foundation design specifications" [S] Beijing: China Communications Press .2007

[3] Chongqing Communications Research and Design Institute of .JTG / TB021-01-2008 "Seismic 
Design of Highway Bridges Rules" [S] Beijing: China Communications Press (2008)

[4] Zhong Aijun, Guan country "bridge seismic" [M] Beijing: China Communications Press .2011

[5] Fan Lichu, Zhuo Weidong "bridge ductile seismic design" [M] Beijing: China Communications Press .2001 